"successful transformative engineering: a system assembled from proven ingredients whose synergies change a mundane experience to such an extent that it becomes not just new but highly desirable".

These comments, and others scattered throughout the introductory chapter of the book, raise expectations of broader insights to be drawn from the detailed case studies presented later. However, subsequent chapters give an unmistakeable sense that Smil has lost control of the process by which his argument might develop, among the details of the case at hand. As a result, the case studies remain in the form of encyclopaedic entries, rather than instances by which the nuances of a more general and complex argument might have developed. To be fair to Smil, he notes in the preface that he has no intention of proposing a great thesis. But the reader cannot help feeling that the enormous effort expended in collecting information throughout the book deserves a rather greater degree of conceptual closure. Nasir Tyabji is director of the Centre for Jawaharlal Nehru Studies, Jamia Millia Islamia, New Delhi 110 025, India.

\title{
Science uncut
}

\section{Sex, Drugs and DNA: Science's Taboos Confronted \\ by Michael Stebbins \\ Macmillan Science: 2006. 360 pp. \\ $\$ 15.72, \notin 16.99$}

\section{Lee M. Silver}

I have fond memories of my middle years as a graduate student working in the Harvard Bio Labs during the mid-1970s. Behind the life-size bronze rhinos that guarded the building, lights burned all night long as my fellow students and I pipetted solutions, ran gels and played with expensive equipment, all to the beat of blasting rock music. Like kids in a sweetshop, we would 'do science' to our hearts' content until we dropped from exhaustion. The next day, we'd wake at some point, throw on some tatty clothes, and think up new experiments. Our chief diversion was smoky weekend parties where a few hip professors would join us, often with an eye for female grad students. On one occasion, a lab-mate synthesized mescaline - following a recipe from Nature - and we had a grand time tripping through Harvard Square and along the banks of the Charles River. The only laws that mattered were the laws of nature, and as far as we were concerned, even those were ripe for attack.

Why was the US government footing the bill for our anarchic endeavours? As long as money flowed into experimental reagents, lab supplies and our measly stipends, we didn't have a clue and we didn't care. With no classes or exams, no children to feed, no possessions of any worth, and not much thought for the future, we could occupy ourselves completely with the subjects covered by Sex, Drugs and DNA, Michael Stebbins' book-length rant about the irreverent lives and world-views of molecular biologists.

Stebbins tells us at the start that he intends to "address the litany of bullshit and lies" that other scientists are afraid to talk about in public. What are some of the hushed-up truths? Genes play a role in behaviour; men and women have anatomically distinct brains; professors can sleep with grad students, as long as they're discreet about it; students entering grad school have no idea what they're in for, and how small their chances are of getting a coveted academic position; there's no good time for an aspiring woman scientist to have a baby; scientists can be selfish and petty; and they can curse with as much abandon as a drunken football fan. Many colleagues will find nothing to quarrel about in these accounts. But how many others will be interested in the anthropology of the cultish molecular-biology tribe is not clear.

Stebbins' ruminations run far beyond work practices, dancing across nearly every major intersection of biological science with society. Some of his observations are right on the mark, such as an in-depth look at the corrupt politics and fraudulent marketing of 'dietary supplements'. Sometimes, however, particularly when he glibly dismisses objections voiced by the 'religious right', Stebbins is guilty, in reverse, of the sin he pins on his 'ignorant' opponents. He writes, for example: "there is nothing in the theory of evolution that really threatens the Christian faith"; opposition to contraception is based on "ridiculous hypocrisy and religionbased stupidity"; and "none of the arguments" made against embryonic stem-cell research "made much sense". Comments such as these fail to provide much insight into these raging controversies.

Scientists should be more suspicious when Stebbins readily accepts the simplistic conventional wisdom spouted by people on the political left about complex environmental issues. He demonizes DDT, for example, as an agent of human birth defects, without providing any quantitative information and without mentioning the role it played in eradicating malaria from US and European shores. Indeed, DDT could save the lives of millions of African children, if used wisely, without any significant negative impact on the environment or health.

Stebbins also reflects the naivety I expressed as a graduate student regarding the larger purpose of government funding of university research. And like many academic scientists, he hasn't delved into economics sufficiently to understand that market forces and intellectualproperty rights provide the greatest incentive for the rapid exploitation of basic science, with respect to the development of pharmaceuticals and other biotech products.

Nevertheless, if you want a taste of the offthe-cuff, vulgarity-tinged musings you're likely to hear after hours in a pub from a bunch of sometimes-uninformed molecular biologists, then, by all means, read this book.

Lee M. Silver is at the Woodrow Wilson School of Public and International Affairs, Princeton University, Princeton, New Jersey 08544, USA. $\mathrm{He}$ is the author of Challenging Nature: The Clash of Science and Spirituality at the New Frontiers of Life (Ecco Press).

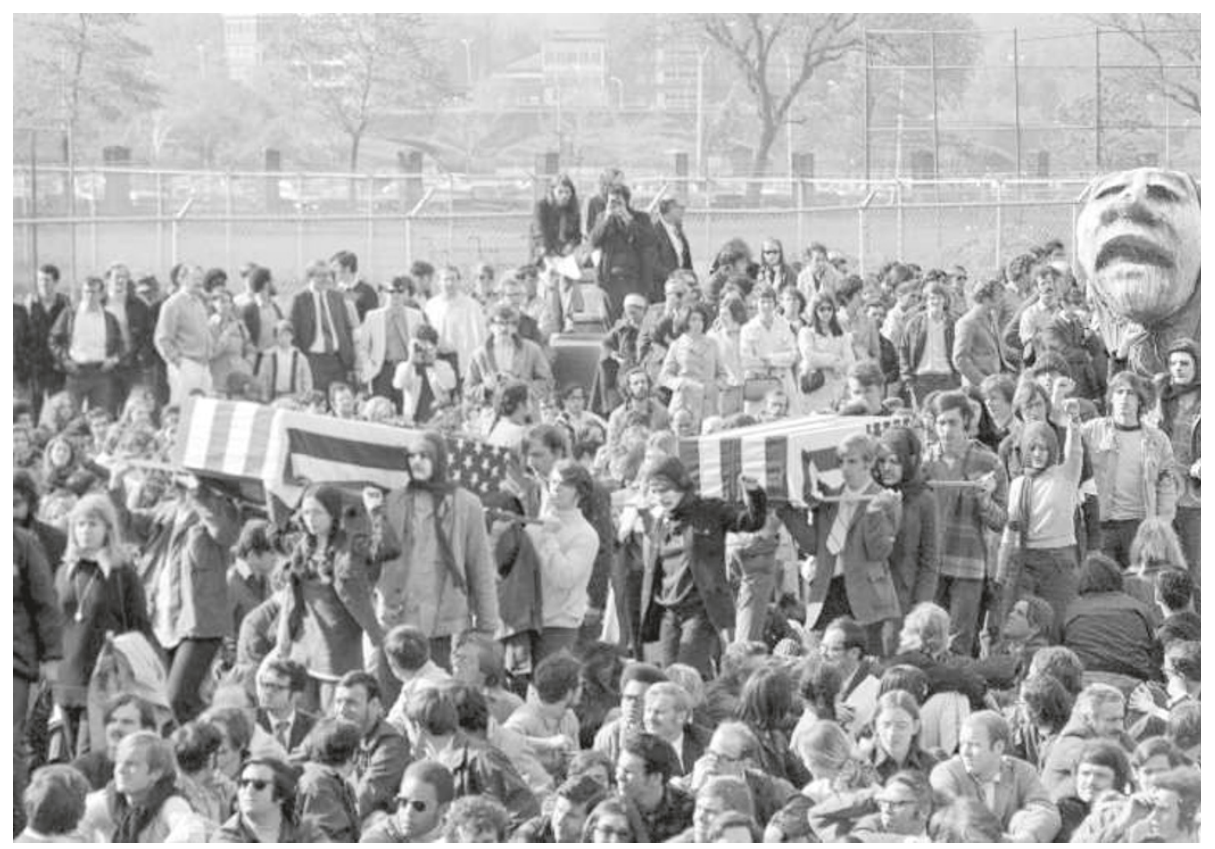

Science and society: students have often engaged with political issues by mounting protests to wars. 